EUROPEAN INDUSTRIAL ORGANISATION 


\section{PROBLEMS OF ECONOMIC INTEGRATION}

General Editor: GEORGE W. McKENZIE

PUBLISHED

European Industrial Organisation

Alexis P. Jacquemin, University of Louvain, and Henry W. de Jong, Netherlands School of Business

The Economics of the Euro-Currency System

George W. McKenzie, University of Southampton

Trade Preferences for Developing Countries

Tracy Murray, Graduate School of Business Administration,

New York University

International Economics of Pollution

Ingo Walter, Graduate School of Business Administration,

New Y ork University

FORTHCOMING

Economic Interdependence

Sven W. Arndt, University of California at Santa Cruz

International Capital Flows

David T. Llewellyn, Loughborough University 


\section{European Industrial Organisation}

ALEXIS P. JACQUEMIN

University of Louvain

and

\section{HENRY W. DE JONG}

Netherlands School of Business 
() Alexis P. Jacquemin and Henry W. de Jong 1977

All rights reserved. No part of this publication may be reproduced or transmitted, in any form or by any means, without permission

First published 1977 by

THE MACMILLAN PRESS LTD

London and Basingstoke

Associated companies in New York Dublin

Melbourne Johannesburg and Madras

ISBN 978-0-333-21102-1 ISBN 978-1-349-86167-5 (eBook)

DOI 10.1007/978-1-349-86167-5

Typeset in IBM Baskerville by

Preface Ltd

Salisbury, Wilts

This book is sold subject to the standard conditions of the Net Book Agreement.

The paperback edition of this book is sold subject to the condition that it shall not, by way of trade or otherwise, be lent, resold, hired out, or otherwise circulated without the publisher's prior consent in any form of binding or cover other than that in which it is published and without a similar condition including this condition being imposed on the subsequent purchaser. 


\section{Contents}

General Editor's Preface vii

Preface ix

1 Industrial Organisation in a European Perspective 1

Competition and industrial organisation 1

A European approach to the structure-conduct-performance paradigm 5

Statistical dimensions of the European economy $\quad 8$

$\begin{array}{ll}\text { Institutional background } & 21\end{array}$

$\begin{array}{ll}\text { Conclusion } & 26\end{array}$

2 Industrial Concentration 27

$\begin{array}{ll}\text { Determinants of size and concentration } & 28\end{array}$

Statistical measures of concentration $\quad 41$

Empirical analysis of European concentration $\quad 50$

$\begin{array}{ll}\text { Vertical integration } & 61\end{array}$

Routes to increased concentration in Europe 68

$\begin{array}{ll}\text { Conclusion } & 78\end{array}$

$\begin{array}{ll}\text { Appendix } & 79\end{array}$

3 Over-all Concentration, Conglomerate Bigness and the Largest European Corporations $\quad 86$

Determinants of size $\quad 87$

Giant European firms $\quad 97$

Conclusion $\quad 114$

$\begin{array}{ll}\text { Appendix } & 114\end{array}$

4 Barriers to Entry, Product Differentiation and Price

Elasticity of Market Demand 118

Types of barriers to entry 118

Barriers to entry in the European context 123

$\begin{array}{ll}\text { Limit-price policies } & 126\end{array}$

Price-elasticity of market demand 131

$\begin{array}{ll}\text { Conclusion } & 132\end{array}$

$\begin{array}{ll}\text { Appendix } & 133\end{array}$

5 Effects of Market Structure and Size on Performance 135

Micro and macro performance: theoretical aspects $\quad 135$

European market structure - performance relationships $\quad 142$

The effects of large European size $\quad 149$

Conclusion $\quad 156$

$\begin{array}{lr}\text { Appendix } & 157\end{array}$ 
6 Objectives and Strategies of the Firm: Static and Dynamic Aspects

The behavioural implications of new business goals 168

Corporate planning and market structure $\quad 176$

Workers' participation and control of the firm 190

$\begin{array}{ll}\text { Conclusion } & 196\end{array}$

7 European Competition Policy: Goals and Means 198

Goals of European competition policy 198

Application of competition rules to the public sector 201

Policy with respect to private restriction of competition: cartels,
concerted practices and dominant positions

Application of Articles 85 and 86 to foreign firms 237

Conclusion 241

8 Roles of Industrial Policy 243

Goals of European industrial policy 244

Industrial policy as a complement to anti-trust policy 247

Industrial policy: conflict with anti-trust policy?

Conclusion 253

References 255

Index 265 


\section{General Editor's Preface}

Since the Second World War, the economies of Europe, North America, Japan and the developing world have become increasingly interdependent. This has taken place at various levels. On the one hand we have seen the formation and growth of a formal organisation, the European Economic Community, whose aim is to strengthen existing political and economic ties amongst its members. But interdependence is not solely the result of legal treaties; it is also the outcome of economic innovation and evolution. The growth of the multinational corporation, the development of the Euro-currency system and the rapid growth of international trade are but examples of the trend.

Yet the resulting closer ties among nations have been a mixed blessing. It is no longer possible for governments to formulate national objectives in isolation from activity in the rest of the world. Monetary, fiscal, anti-trust and social policies now have widespread implications beyond national frontiers. How to cope with the complex implications of the current petroleum price developments is but an example of the sort of problem arising in an interdependent world.

Despite its obvious importance most economics textbooks give only cursory attention to international economic interdependence. The purpose of this series is to fill this gap by providing critical surveys and analyses of specific types of economic linkages among nations. It is thus hoped that the volumes will appeal not only to students, researchers and government bodies working in the field of international economics but also to those dealing with the problems of industrial organisation, monetary economics and other aspects of public policy which have traditionally been studied from a narrow, nationalistic viewpoint.

Department of Economics Southampton University

GEORGE W. McKENZIE 


\section{Preface}

Most textbooks on industrial economics are written by American scholars for American audiences. Accordingly the issues treated and evidence offered are those generated by the structure and functioning of North American markets. It could be maintained that the classic concepts and theories elaborated in this context can be applied usefully in explaining the operation of other industrialised economies such as the European one.

However, we have felt that since industrial economics is concerned with the structure and functioning of markets in the real world, it would be too simplistic to transfer this general framework on to the European industrial scene without any adaptation. At present, the Common Market is a well established institution with its proper nature, strengths and weaknesses; data on it is becoming available and common fields of concern are arising; common options in matters of industrial and competition policy are being determined. For all these reasons we think it indispensable to take into account the particular characteristics of Europe, both with respect to the relative importance attached to the subjects studied and the available theories, as well as concerning the empirical analyses undertaken and the institutional context. Otherwise the explanatory power of the industrial-economics approach would be rendered much less effective.

It is not our intention to present a handbook covering all the matters that come under the heading of 'industrial organisation'; there already exist some excellent Anglo-American textbooks that serve this purpose. Our aim is to construct a synthesis of what seems to us to be the main poles of reflection with regard to European industry today. However, the book does follow the traditional outline of industrial-organisation texts. Thus, in the following pages, we review successively:

(i) the set of market structures and their evolution over time (Chapters 2-4);

(ii) the relationship between structure and performance (Chapter 5);

(iii) the goals and behaviour of business firms (Chapter 6); and

(iv) anti-trust and industrial policies (Chapters 7 and 8).

We have tried to bring out the characteristics of the European 
approach and the manner in which it contrasts with but also resembles the North-American scene. Thus, for example, we insist particularly on the behaviour of firms which is likely to mould the still floating structures of the Common Market; we stress the way in which firms are financially controlled and the role of holding companies; we discuss the calling into question of economies organised according to the capitalistic mode in favour of labour management of various kinds; and, finally, we analyse the conflicts arising between European anti-trust policies and industrial policies resulting from the co-ordination of activity and the various forms of planning agreement between industry and the state.

As a result this book is primarily designed as a treatise on the main topics in industrial organisation and public policy for European students who have already mastered a solid course in microeconomic theory; it could also be considered as a useful complementary text for American students in industrial economics. Finally, we should like to think that the book might attract an audience of economists and businessmen who wish to obtain a wider view of European industrial economics.

This work, however, is only a first step towards a better understanding of European industrial economics, which is still strongly heterogeneous, in a state of constant change and for which comparable data are difficult to obtain.

Several imperfections in the manuscript were corrected in time by the 'visible hand' of good friends. We wish to express our gratitude to Kenneth George (Cardiff University) and William Adams (University of Michigan), who voiced both general and detailed criticisms most of which have been taken into account. We are also indebted to Alfred Steinherr (University of Louvain), who made several valuable suggestions and, not least, to Caroline Joll (Cardiff University), who undertook the arduous task of improving the English text, meanwhile suggesting substantial changes. Finally, our thanks are due to Anne Sibille of the European Institute for Advanced Studies in Management (Brussels) whose task it was to type a perpetually changing manuscript. Of course the responsibility for any errors or ambiguities which remain has to be totally imputed to the authors.

ALEXIS P. JACQUEMIN

HENRY W. DE JONG 